\title{
Wychowanie w rodzinie jako czynnik ksztaltujący postawę tolerancji społecznej
}

Tolerancja jest obecnie tematem dyskusji zarówno w mediach, jak i w przestrzeni naukowej. W związku z tym pojawia się wiele przeciwstawnych opinii ${ }^{1}$. Mieszczą się one w szerokim zakresie znaczeniowym, łączącym ujęcia skrajne i całą przestrzeń pomiędzy nimi. O ile w dyskusji społecznej dominuje problematyka pola znaczeniowego pojęcia tolerancja, to w pedagogice zwraca się uwagę na kształtowanie postaw tolerancyjnych:

Priorytetowym zadaniem jest rozwijanie kultury tolerancji przejawiającej się w zdobywaniu wiedzy o drugim człowieku, zrozumieniu źródeł i motywów postępowania, wyrozumiałości dla inności drugiego człowieka, poszanowanie godności własnej i drugiego, umiejętności rozwiązywania konfliktów, prowadzenia dialogu, argumentowania, prowadzenia dyskusji, akceptacji zasady pluralizmu².

Tak ściśle określone zadania domagają się zastosowania odpowiednich metod wychowawczych, które pozwolą na osiągnięcie poprawy jakości funkcjonowania relacji społecznych.

\footnotetext{
${ }^{1}$ Por. J. Ambrosewicz-Jacobs, Tolerancja. Jak uczyć siebie i innych, Kraków 2004; J. Balsamska, $\mathrm{i}$ in., Pomiędzy tolerancją a dyskryminacja, Kraków 2012; Tolerancja i wielokulturowość. Wyzwania XXI wieku, red. A. Borowiak, P. Szarota, Warszawa 2004; M. Czyżewski, Tolerancja i nietolerancja: pojęcia i postulaty, „Etyka” 44 (2011), s. 58-78; J. Dąbrowski, Wspótistnienie, koegzystencja, „Emocje” 1 (2013), s. 23-27; U. Eco, Pięć pism moralnych, Kraków 2008, s. 89-109; B. Majerek, Młodzież wobec innych. Studium empiryczne na temat nietolerancji społecznej, Kraków 2005, s. 10-13; A. P. F. Sell, Chrześcijaństwo, sekularyzm i tolerancja: liberalne wartości i nieoświecone postawy, [w:] Literatura, kultura, tolerancja, red. G. Gazda, I. Hübner. J. Płuciennik, Kraków 2008, s. 267-291.

${ }^{2}$ K. Chałas, Wychowanie ku wartościom. Elementy teorii i praktyki, t. 1, Lublin-Kielce 2006, s. 232.
} 
Proces wychowania człowieka jest nierozłącznie związany z rodziną i oddziaływaniami, które się w niej dokonują. Wychowanie przyczynia się do uznania godności oraz równości innych ludzi jako należących do wspólnoty ludzkiej³. Dlatego wydaje się, że wskazanie rodziny jako środowiska mającego zasadniczy wpływ na wychowanie do postawy tolerancji jest w pełni uzasadnione. Nie istnieje środowisko, które w bardziej naturalny sposób łączyłoby ideę dobra dziecka z potrzebą kształtowania jego prospołecznych postaw. Wydaje się jednak, że nie każda rodzina w pełni korzysta ze swego potencjału wychowawczego. Społeczeństwo wymaga od rodziny określonych postaw, niejednokrotnie nie okazując jej należytego wsparcia w ich realizacji. Dodatkowym czynnikiem utrudniającym wychowanie do tolerancji społecznej jest niejasne określenie, czym w rzeczywistości jest tolerancja i jakie oddziaływania należy podjąć, by urzeczywistnić jej ideał.

Aby przybliżyć zagadnienie wychowania do postawy tolerancji w rodzinie, konieczne jest ukazanie znaczenia omawianej kategorii oraz związanych z nią odniesień pedagogicznych. W tym celu zasadne będzie odwołanie się do personalizmu chrześcijańskiego i jego założeń wychowawczych. Kolejnym etapem będzie zaprezentowanie czynników zakłócających proces wychowania do omawianej wartości. Ponieważ prospołeczne wychowanie w tradycyjnej rodzinie jest coraz częściej kwestionowane, konieczne będzie określenie znaczenia rodziny w procesie formowania społeczeństwa tolerancyjnego. Wskazanie rodzinnych uwarunkowań tego procesu pozwoli na podkreślenie istotnych czynników, które mogłyby właściwie ukierunkować i usprawnić proces wychowania do życia otwartego na innych ludzi.

\section{Pedagogiczne znaczenie tolerancji}

Przystępując do analizy wychowawczego kontekstu tolerancji, należałoby zaprezentować bogaty zakres definicji tego pojęcia. Jednak trzeba podkreślić, że próba zdefiniowania kategorii tolerancji jest źródłem wielu trudności. Są one związane z różnymi podejściami do omawianego zagadnienia, a w rzeczywistości z odmiennymi koncepcjami człowieka. Ta uwaga wydaje się istotna, ponieważ „u podstaw tolerancji znajduje się człowiek, jego działania, poglądy, opinie, sposób życia" ". Wartość osoby ludzkiej wydaje się więc jednym z fundamentalnych założeń tolerancji.

Spojrzenia na osobę ludzką są dzisiaj bardzo odmienne. Liczba definicji tolerancji przekracza możliwości objętościowe niniejszego artykułu, dlatego słuszne wydaje się podkreślenie, iż przegląd definicji tolerancji, jej podziałów i znaczeń zostanie

\footnotetext{
${ }^{3}$ P. Kroczek, Wychowanie. Optyka prawa polskiego i prawa kanonicznego, Kraków 2013, s. 48.

${ }^{4}$ K. Chałas, Wychowanie..., dz. cyt., s. 201.
} 
potraktowany w sposób wybiórczy i będzie analizowany przede wszystkim pod kątem wychowawczym.

W ujęciu filozoficznym tolerancja może przybierać przynajmniej trzy znaczenia. Pierwsze to znaczenie negatywne, które podkreśla brak interwencji i znoszenie zachowań i poglądów. Drugie znaczenie jest pozytywne i obejmuje działania jednostki na rzecz szerzenia szacunku dla odmienności, trzecie natomiast określa tolerancję jako brak przymusu wobec partnerów interakcji i postuluje stworzenie dla osób myślących inaczej obszaru wolności ${ }^{5}$.

Wydaje się, że przedstawiony trójpodział filozoficznego znaczenia tolerancji można nieco uprościć. Według Ewy Podrez powszechnie znane definicje tolerancji nie oddają w pełni jej znaczenia, stąd można przyjąć, iż ,tolerancji przysługują dwa podstawowe znaczenia: pierwsze z nich to pobłażliwość, okazywanie cierpliwości i wyrozumiałości; drugie to afirmacja lub popieranie cudzej odmienności, a także szacunek dla jego autonomii i wolności"'. Wydaje się, że pedagogiczny charakter niniejszej pracy usprawiedliwia przyjęcie do dalszych rozważań dychotomicznego podziału tolerancji. Pierwsza postawa postuluje niesprzeciwianie się złu, a druga - życzliwość wobec osoby, której poglądy nie są akceptowane. W znaczeniu pozytywnym tolerancja jest formą działania, zaangażowania, czyli

postawą charakteryzującą się: otwartością na drugiego człowieka, uznaniem jego wartości, afirmacją godności osoby ludzkiej, przeżywaniem człowieczeństwa w spotkaniu i dialogu z drugim, poszukiwaniem obiektywnego dobra (dobra osoby, wspólnoty, dobra wspólnego). Tak rozumiana tolerancja nie zawsze odnosi się z aprobatą i zgodą do działań i zachowań osoby, natomiast zawsze wyraża się w niej akt tolerancji osoby ze względu na jej godność i wartość7.

Takie spojrzenie na postawę tolerancji pokazuje, iż jest ona sama w sobie wartością, która uzasadnia swą rację bytu godnością człowieka. Jednocześnie broni wartości, które są zagrożone w życiu społecznym.

\section{Tolerancja negatywna}

Tolerancja negatywna nawiązuje do źródłosłowu łacińskiego (łac. tolerantio-znoszenie, cierpliwość, wytrzymywanie, cierpienie) i wskazuje na wysiłek konieczny do jej zastosowania. Omawiając to znaczenie, Józef Maria Bocheński zwraca uwagę, że tolerancja to

${ }^{5}$ Por. A. J. Siegień-Matyjewicz, Tolerancja, [w:] Encyklopedia pedagogiczna XXI wieku, red. T. Pilch, t. 6, Warszawa 2007, s. 696.

${ }^{6}$ E. Podrez, Tolerancja - problemy i dylematy nie tylko moralnej natury, [w:] Tolerancja i kulturowość..., dz. cyt., s. 16.

${ }^{7}$ K. Chałas, Wychowanie..., dz. cyt., s. 204. 
tyle co znoszenie. Nazywamy „tolerancyjnym” człowieka, który toleruje, to jest znosi innych, ich poglądy, ich sposób życia itp. Tolerancja jest wypróbowanym sposobem współżycia tego samego społeczeństwa różnych grup ludzi, różniących się pod względem światopoglądu.

Definicja podkreśla, że postawa ta została sprawdzona w praktyce ludzkiej koegzystencji i okazała się użyteczna.

W ujęciu negatywnym tolerancja może oznaczać całkowitą pasywność wobec osób bądź sytuacji. Tolerancja negatywna jest poddawana krytyce ze względu na związane z nią niebezpieczeństwo, zwłaszcza w kontekście wychowawczym. Może się bowiem pojawić obojętność wobec zachowań innych, będąca formą akceptacji poglądów i zachowań niezgodnych z dobrem społeczeństwa: „Obojętność nie zawiera elementu etycznego a nawet wydaje się ograniczać aktywność poznawczą wobec przedmiotu oceny. Jest to jakaś postać egocentryzmu, który nie wyróżnia pojęcia interesów pozaosobistych, zagrożenia dla wartości publicznych"9. Bierność często wyraża się w akceptacji poglądów i zachowań, które ze względów społecznych winny być napiętnowane. Ta forma tolerancji występuje tam, gdzie konformizm bierze górę nad uczciwością i prawdą: „Wskaźnikiem postawy tolerancji negatywnej jest zgoda na zachowania, które negatywnie oceniamy, a które mieszczą się w przestrzeni wolnego działania człowieka"10. Negatywna tolerancja może doprowadzić do uprzedmiotowienia wychowanka oraz do patologii społecznych.

Wydaje się, że istnieje także inne znaczenie tolerancji ujmowanej od strony negatywnej. Tolerancja może być rozumiana zgodnie z koncepcją m.in. Johna Locke'a, który postrzegał ją jako niepodejmowanie działań ze względu na szacunek do drugiego człowieka: „Jestem tolerancyjny, jeśli nie prześladuję, nie żądam prześladowań i nie zachowuję się agresywnie w stosunku do kogoś, kogo nie lubię, chociaż nie aprobuję tego, co mnie razi albo budzi moją niechęć"11. Niekiedy wstrzymanie się od aktywności może być wyrazem miłości wobec kogoś, kto ma odmienne poglądy. Powstrzymanie się od działań mających na celu zmianę przekonań może być oparte nie na wygodnictwie, ale na zdrowym rozsądku i odwadze: „Trzeba podkreślić, jak ważna rola, obok rozsądku, przypada odwadze w podejmowaniu decyzji moralnych. Wydaje się, że tolerancja negatywna wymaga tej odwagi w stopniu tak wielkim, że często zbliżonym do heroizmu" ${ }^{12}$. Można przyjąć, że tolerancja negatywna jest uzasadniona, jeśli jej granice są wyraźnie określone, a jednocześnie akceptuje się

${ }^{8}$ J. M. Bocheński, Sto zabobonów. Krótki filozoficzny słownik zabobonów, Kraków 1994, s. 129.

${ }^{9}$ T. Pilch, Agresja i nietolerancja jako mechanizmy zagrożenia ładu społecznego, [w:] Pedagogika społeczna, red. T. Pilch, I. Lepalczyk, Warszawa 1995, s. 426.

${ }^{10}$ K. Chałas, Wychowanie..., dz. cyt., s. 207.

${ }^{11}$ Z. Chlewiński, Dylematy tolerancji. Refleksje o charakterze edukacyjnym, [w:] J. Brzeziński, Z. Kwieciński, Polacy na progu, „Forum Oświatowe” 1-2 (1997), s. 165.

${ }^{12}$ E. Podrez, Tolerancja ..., dz. cyt., s. 22. 
dobra i prawa ludzi. W stosunku do zachowań i poglądów człowieka może więc obowiązywać ograniczona tolerancja negatywna.

\section{Tolerancja pozytywna}

Pozytywne ujęcie tolerancji akcentuje potrzebę akceptacji i partnerstwa: „Tolerancja pozytywna polega na świadomej akceptacji odmienności, która jest aktem afirmacji ludzkiej wolności i autonomii" ${ }^{13}$. Ujęcie to poszerza semantyczne znaczenie tolerancji. Spojrzenie na drugiego człowieka bez stereotypów i negatywnych obciążeń kulturowych pozwala na dostrzeżenie elementów wspólnych oraz właściwe potraktowanie tego, co odmienne. Można więc przyjąć, że dominantą tego ujęcia jest

akceptacja i afirmacja osoby (lub wspólnoty osób), chęć współdziałania, bycia ze sobą w duchu partnerstwa, przyjaźni i dialogu w kontekście dóbr, wartości i norm moralnych. Spotkanie, dialog, współuczestnictwo międzyosobowe konstytuują wartości mające swe źródło w normie personalistycznej ${ }^{14}$.

Wydaje się, że w powyższej definicji należy szczególnie podkreślić wyraźne odniesienie aksjologiczne oraz obecność norm moralnych, które chronią wartości. Odwołanie do normy personalistycznej przypomina o potrzebie bycia i stawania się sobą oraz budowania dobra przez swoje postępowanie ${ }^{15}$. W ten sposób tolerancja nie prowadzi do relatywizacji wartości i postaw moralnych, co stanowi bardzo istotny aksjomat pedagogiczny. Afirmacja i otwarcie na drugiego człowieka nie wyklucza więc zachowania poczucia tożsamości, odrębności i niezależności. Wychowanie do tak rozumianej tolerancji wydaje się jednym z fundamentalnych zadań stojących przed rodziną.

Pedagogika oparta na założeniach personalizmu domaga się wyznaczenia granic tolerancji, które są konieczne, jeśli omawiana kategoria ma mieć znaczenie społeczne i wychowawcze. Potrzeba ustalenia zakresu tolerancji wypływa także z jej założeń - skoro ogniskuje ona w sobie wiele wartości, to może pojawić się konieczność zapewnienia ich nienaruszalności. Dzięki granicom można pokazać zagrożenia, jakie mogą pojawić się w procesie jej realizacji.

\section{Czynniki zagrażające wychowaniu do tolerancji}

Współczesne spojrzenie na tolerancję coraz częściej bywa liberalne. W tym ujęciu można zauważyć, że „w wypadku tolerancji pozytywnej chodzi nie tyle o niedziałanie,

\footnotetext{
${ }^{13}$ Tamże, s. 22.

${ }^{14}$ K. Chałas, Wychowanie..., dz. cyt., s. 213.

${ }^{15}$ Por. tamże.
} 
ile o wspieranie osoby, z której racjami czy obyczajami się nie zgadzamy, ale której prawa uznajemy, wiedząc, że powszechnie uznawane nie są"16. W tym znaczeniu tolerancja oznacza nie tylko akceptowanie prawa do inności, ale także dążenie do tego, by te prawa były rzeczywiście respektowane. Wydaje się, że w tym założeniu kryje się sprzeczność, która ma istotne odniesienie wychowawcze. Pojawia się bowiem pytanie, na ile można zabiegać o prawa, z którymi się jednostka osobiście nie zgadza i czy nie dochodzi w tej sytuacji do uczenia działania wbrew sobie.

Tolerancja, podobnie jak każda wartość, może zostać zagrożona. Dzieje się tak wówczas, gdy zamiast postawy otwartej na drugiego człowieka pojawia się nietolerancja. Można podać kilka współczesnych egzemplifikacji tego pojęcia. W klasycznym ujęciu nietolerancja jest zaprzeczeniem prawdziwej tolerancji. Ta aspołeczna postawa może być pojmowana jako

zachowanie lub opinia skierowana przeciwko ludziom, zjawiskom i wartościom, które „nam” nie odpowiadają, są ,inne”, w celu ich zmiany lub zniszczenia, mimo że ich istnienie jest uprawnione przez prawa natury, obyczaj, moralność ${ }^{17}$.

Z całą pewnością postawa nietolerancji stanowi zaprzeczenie idei godności osoby oraz zasad życia społecznego. Jest też postawą antywychowawczą, gdyż powiela i utrwala stereotypy krzywdzące poszczególne osoby czy grupy społeczne. Z tych względów nie można akceptować dyskryminacji ze względu na kolor skóry, pochodzenie, wyznawaną religię czy poglądy.

Obok klasycznego ujęcia nietolerancji szerokie spojrzenie na omawiane zagadnienie pozwala dostrzec inne przejawy niewłaściwego rozumienia tolerancji, które czasem trudno sobie uświadomić. Jest to jednak konieczne, gdyż mają one bardzo wyraźne odniesienie do procesu wychowania.

Tolerancja przybiera niekiedy cechy absolutystyczne. Pojawia się wtedy niebezpieczeństwo ideologizacji:

Tolerancja zobowiązuje do akceptacji drugiej osoby, jej poszanowania, traktowania po ludzku. Powyższe zachowania nie oznaczają bezgranicznej akceptacji, gdyż prowadzić może ona do budowania przestrzeni zła, w której człowiek jest poniżony i niszczone są najwyższe wartości. Nieograniczona tolerancja prowadzi do zaniku tolerancji ${ }^{18}$.

Warto podkreślić, że wyznaczenie granic tolerancji nie oznacza pozbawienia człowieka jego godności, gdyż tolerancja domaga się uznania zawsze i wszędzie. Natomiast niektóre poglądy czy działania nie zawsze powinny być akceptowane.

\footnotetext{
${ }^{16}$ M. Środa, Mała ksiązka o tolerancji, Warszawa 2010, s. 33.

${ }^{17}$ T. Pilch, Agresja ..., dz. cyt., s. 428.

${ }^{18}$ K. Chałas, Wychowanie..., dz. cyt., s. 204.
} 
Otwarcie na drugiego człowieka, które inspiruje do podejmowania dialogu, nie polega na akceptacji czy popieraniu wszystkich przejawów autonomii innych ${ }^{19}$. Tolerancja nabiera znaczenia wartościującego pod warunkiem, że prowadzi do wyższych od siebie wartości, takich jak prawda, miłość, dobro.

Wydaje się, że równie niekorzystnym zjawiskiem jest sytuacja, w której tolerancja sama $\mathrm{w}$ sobie staje się przedmiotem tolerancji, czego konsekwencją jest fakt, że większość jest dyskryminowana przez mniejszość ${ }^{20}$. W tym kontekście wydaje się, że domaganie się zrównania praw mniejszości społecznych z prawami przysługującymi większości jest nadużyciem pojęcia tolerancji. Jest to widoczne zwłaszcza wówczas, gdy od większości domaga się zrezygnowania z przysługujących jej praw w imię idei równości, pojmowanej jako wartość nadrzędna.

Pozytywny wymiar tolerancji może zostać nadużyty poprzez proponowanie zachowań społecznych, które są sprzeczne z ideą wychowania opartego na wartościach oraz zasadami współżycia społecznego. Jednym z przykładów może być lansowanie wśród młodego pokolenia udziału w paradach równości tylko po to, by wspierać prawa homoseksualistów, chociaż nie należy się do tej grupy osób ${ }^{21}$.

Równie nierealne, a zarazem niebezpieczne dla wychowania jest podejście, które wyraża się w pozostawieniu dziecku swobody w podejmowaniu decyzji. Wiąże się to niekiedy z koniecznością sprzeciwienia się woli wychowawców:

Czy dzieci mają prawo w pewnych sytuacjach zachowywać się tak, jak same chcą, a nie tak, jak chcieliby rodzice i opiekunowie? Z pewnością, jeśli się tylko nawzajem nie krzywdzą, nie łamią praw, nie obniżają poziomu nauczania, a ich styl życia nie kłóci się z obowiązkami ucznia. Wobec dzieci należy być tolerancyjnym ${ }^{22}$.

$\mathrm{Z}$ jednej strony wypowiedź ta broni praw dziecka, których przestrzeganie jest niezbywalnym obowiązkiem dorosłych, ale w kontekście wychowawczym pogląd ten stwarza niebezpieczeństwo niewłaściwego wykorzystania wolności przez dziecko.

Założenie, że wybory dziecka sprzeczne z wolą wychowawców w żaden sposób nie wpłyną na obniżenie jakości funkcjonowania dziecka w szkole i w domu, wydaje się utopijne. Przeciwstawienie się wychowawcy jest konieczne, gdy chodzi o obronę najwyższych wartości, ale takie sytuacje zdarzają się bardzo rzadko. Sugestia, że sprzeciwienie się woli dziecka jest uczeniem go nietolerancji, jest nieuprawnionym nadużyciem. Ukazanie naturalnego wychowania w rodzinie jako zagrożenia dla postawy tolerancji wydaje się nieuprawnione, bo w takiej sytuacji narzuca się dziecku poglądy i sposoby zachowań: „Profesjonalna edukacja pozwala kształtować

\footnotetext{
${ }^{19}$ Por. E. Podrez, Moralne uzasadnienie tolerancji, Warszawa 1999, s. 315.

${ }^{20}$ Por. A. J. Siegień-Matyjewicz, Tolerancja, dz. cyt., s. 699.

${ }^{21}$ M. Środa, Mała ksiażka..., dz. cyt., s. 32.

${ }^{22}$ Por. tamże, s. 20-21.
} 
postawy, przekazywać wiedzę niezbędną do zgodnego współistnienia z przedstawicielami odmiennych kultur, odrzucać negatywne stereotypy narodowościowe, często wyniesione z rodzinnego domu"23. Wydaje się, że skojarzenie wychowania w rodzinie z kształtowaniem postaw nietolerancji jest nadużyciem, nawet jeśli poszczególne przypadki nietolerancji mogą mieć wspomnianą genezę. Skoro jednak to spojrzenie jest obecne we współczesnej dyskusji społecznej, należy przedstawić zarys aksjologiczny wychowania do tolerancji w rodzinie.

\section{Rodzinne uwarunkowania wychowania do tolerancji}

Rodzina jest wspólnotą osób, które kształtują sposób myślenia, przeżywania oraz zachowania się jednostki. Jest przestrzenią, w której dziecko zostaje wprowadzone w normy życia społecznego, dzięki czemu kształtuje się jego osobowość etyczna. Konstytuująje wartości, których przekazywanie jest jednym z istotnych zadań rodziny ${ }^{24}$.

W tej perspektywie wychowanie do wartości stanowi istotną treść życia prawidłowo funkcjonującej rodziny. Tolerancja stanowiąca wartość odsłaniającą inne, wyższe wartości jest celem działań wychowawczych rodziny świadomej swego posłannictwa. Wychowanie do wartości realizowane w rodzinie dokonuje się $\mathrm{w}$ dużym stopniu przez uczestnictwo w codziennym życiu. Istotną rolę odgrywają w nim postawy rodziców. Mogą one pomóc w rozwoju osobowości dziecka bądź przyczynić się do jego regresu.

\section{Wpływ postaw rodzicielskich}

Jednym z wyznaczników rozwoju wychowanka jest kształtowanie się w nim postawy dobrze rozumianej tolerancji społecznej, dlatego istotne wydaje się przedstawienie typologii postaw rodzicielskich, mających wpływ na rozwój dziecka. W klasycznym ujęciu postaw rodzicielskich występuje kilka typowych podejść, które zostaną omówione poniżej ${ }^{25}$.

Akceptacja dziecka i jego potrzeb

Akceptacja dziecka, która ma poważne konsekwencje wychowawcze, jest fundamentalnym zadaniem rodziców. Rodzice tworzący rodzinę wydolną wychowawczo

${ }^{23}$ Dezyderat nr 3 Komisji Mniejszości Narodowych i Etnicznych Sejmu RP uchwalony na posiedzeniu w dniu 22 maja 2013 r. do Ministra Edukacji Narodowej w sprawie edukacji wielokulturowej, www.orka.sejm.gov.pl (30.06.2013).

${ }^{24}$ Por. A. Błasiak, E. Dybowska, Wybrane aspekty procesu wychowania w rodzinie, [w:] Wybrane zagadnienia pedagogiki rodziny, red. A. Błasiak, E. Dybowska, Kraków 2010, s. 185.

${ }^{25}$ Por. M. Ziemska, Postawy rodzicielskie, Warszawa 1973, s. 57-59. 
akceptują dziecko na wielu poziomach jego funkcjonowania ${ }^{26}$. W oczach rodziców dziecko jest cenne przez sam fakt istnienia. Poczucie bycia drogocennym rodzi wrażliwość na poszanowanie godności własnej, jak i innych. Rodzice akceptujący bezbronność dziecka utwierdzają je w przekonaniu, że należy szanować bezbronność słabszych i nie można dyskryminować ich tylko dlatego, że są słabsi. Akceptacja niedoskonałości członków rodziny utwierdza dzieci w przekonaniu, że niedoskonałość jest atrybutem związanym z ludzką egzystencją i wiąże się z odpowiedzialnością za swoje czyny. Funkcjonalni rodzice akceptują zależność dziecka, która w procesie wychowawczym przeradza się w samodzielność i zdolność do poprawnego zaspokajania swoich pragnień. Niedojrzałość dziecka w rodzinie wydolnej wychowawczo jest szanowana i uznawana za jego naturalną cechę $e^{27}$. Dziecko wzrasta w przekonaniu, że każdy ma prawo w swoim tempie dojrzewać i dorastać do pełnienia określonych ról społecznych. W ten sposób kształtuje się postawa tolerancji wobec innych.

\section{Współdziałanie z dzieckiem}

Postulat traktowania dziecka jako podmiotu leży u podstaw personalistycznego procesu wychowania. Współdziałanie z dzieckiem w kształtowaniu jego rozwoju jest jednym z zasadniczych założeń stylu wychowania o odcieniu demokratycznym:

Istotną jego cechą jest dopuszczenie dziecka do współdziałania w życiu rodziny: dziecko wraz z rodzicami i innymi członkami rodziny omawia i dyskutuje rozmaite sprawy codzienne, planuje i organizuje sposób spędzania wolnego czasu [...], uczy się także liczyć ze zdaniem innych i z ich interesami oraz współdziałać z rodzicami i rodzeństwem przy każdej okazji i udzielać im pomocy w razie potrzeby. Daje to pole do rozwijania własnej inicjatywy oraz kształci postawy prospołeczne ${ }^{28}$.

Tolerancja zaliczana do podstawowych postaw oczekiwanych przez społeczeństwo najpełniej rozwija się w warunkach demokratycznego stylu wychowania pod warunkiem, że nie przyjmuje on jednej z form pozornej demokratyzacji życia. Jednym z przykładów niewłaściwych relacji wychowawczych, o której przypomniał Jan Paweł II w 1999 roku, jest „skłonność wielu rodziców, by wyrzekać się właściwej sobie roli i przyjmować postawę zwykłych przyjaciół dzieci, co oznacza, że nie napominają ich i nie strofują nawet wówczas, gdy powinni to czynić - z miłością i czułością - aby wychowywać je w prawdzie"29. Zachowanie właściwych sobie ról społecznych pełnionych $\mathrm{w}$ rodzinie jest jednym $\mathrm{z}$ istotnych warunków kształ-

${ }^{26}$ Por. S. Kawula, Rodzina o skumulowanych czynnikach patogennych, [w:] Pedagogika rodziny. Obszary i panorama problematyki, red. S. Kawula, J. Brągiel, A. W. Janke, Toruń 2007, s. 149-150.

${ }^{27}$ Por. tamże.

${ }^{28}$ M. Przetacznik-Gierowska, Z. Włodarski, Psychologia wychowawcza, t. 2, Warszawa 1998, s. 130.

${ }^{29}$ Jan Paweł II, Przemówienie do Zgromadzenia Plenarnego Papieskiej Rady ds. Rodziny (4 czerwca 1999), „L'Osservatore Romano”, wydanie polskie, 11 (1999), s. 6. 
towania postawy współdziałania. Świadomość własnej tożsamości oraz potrzeby współdziałania dla wspólnego dobra jest wskaźnikiem postawy tolerancji.

Rozumna swoboda

Swoboda dziecka może przybierać dwie formy. Może być w mniejszym lub większym stopniu kontrolowana albo absolutna. Niekontrolowana swoboda dziecka stanowi podstawę wychowania liberalnego, akcentującego wolność dziecka:

To absolutna zdolność człowieka. Każdy od chwili narodzin dysponuje zdolnością do samodzielnego podejmowania decyzji. Istnieje ona niezależnie od zgody lub zakazu innych ludzi, tak jak ręce, oddychanie, jedzenie czy picie. Dorośli nie muszą nic robić, aby dzieci mogły decydować o sobie.

One to robią od chwili narodzin ${ }^{30}$.

Nieingerowanie w swobodny rozwój dziecka, stanowiące podstawowe założenie antypedagogiki, wypacza ideę wolności w wychowaniu. Pozornie sprzyja wychowaniu do tolerancji, a w rzeczywistości prowadzi do przyjęcia jednej z jej zredukowanych form, opartych na konformizmie.

Na przeciwnym biegunie stylów wychowania znajduje się wychowanie autokratyczne. Obecnie jest ono poddawane miażdżącej krytyce jako styl będący zaprzeczeniem postawy tolerancji wobec dzieci. Wydaje się, że rzeczywiście sprzyja ono kształtowaniu postaw zamkniętych na innych ludzi, nietolerujących zachowań niezgodnych z pożądanymi przez wąską grupę społeczną, traktujących przemoc jako rozwiązanie konfliktów międzyosobowych. Dzieje się tak w przypadku jego skrajnego ujęcia, które opiera się na represji i pełnym surowości nadzorze ${ }^{31}$. Istnieje jednak odmiana wychowania autorytarnego, w której obowiązują jasne zasady postępowania, a zachowania dziecka są kontrolowane, ale jednocześnie ważna jest życzliwość, wzajemne okazywanie uczuć oraz wzajemna komunikacja ${ }^{32}$. Takie wychowanie nie wyklucza kształtowania postawy tolerancji, choć należy przypuszczać, że najczęściej osiąganym efektem wychowawczym będzie tolerancja w ujęciu negatywnym - nieangażująca się w budowanie mostów nad innością, ale też niemająca nic wspólnego $\mathrm{z}$ akceptacją zła czy agresją wobec osób mających inne poglądy. Należy zaakceptować fakt, że w polskich rodzinach styl autorytarny jest wciąż obecny, ale trzeba dbać o to, by nie przyjmował on postaci skrajnej, rygorystycznej postawy rodziców względem dzieci.

\footnotetext{
${ }^{30}$ H. von Schoenebeck, Antypedagogika. Być i wspierać zamiast wychowywać, Warszawa 2007, s. 126.

${ }^{31}$ Por. T. Hovorun, Wptyw stylu wychowania rodzinnego na poprawny rozwój osobowości, [w:] Partnerstwo w rodzinie. Istota i uwarunkowania relacji między rodzicami i dziećmi, red. J. Truskolaska, Lublin 2009, s. 28-30.

${ }^{32}$ Por. M. Przetacznik-Gierowska, Z. Włodarski, Psychologia ..., dz. cyt., s. 130.
} 


\section{Uznanie praw dziecka}

Współczesna rodzina, podlegająca wielu zmianom, w coraz większym stopniu koncentruje wysiłki rodziców na dziecku. Ewolucja wzajemnych powiązań członków rodziny, związana z przechodzeniem tej grupy społecznej od związku gospodarczego do związku osobowego, a także od więzi rzeczowej do osobistej ${ }^{33}$, spowodowała, że coraz częściej mówi się o prawach dziecka. W model rodziny, w którym prawa dziecka są przestrzegane, lecz nie absolutyzowane, wpisuje się nauczanie Jana Pawła II, według którego w rodzinie ,szczególną troską winno być otoczone dziecko; należy rozwijać głęboki szacunek dla jego godności osobistej oraz ze czcią i wielkodusznie służyć jego prawom"34. Respektowanie praw dziecka jest modelowaniem jego postępowania w przyszłości, kiedy wychowanek zostanie skonfrontowany z prawami innych. Doświadczenie wyniesione z domu w dużym stopniu będzie kreowało postawę szacunku wobec spotkanych ludzi oraz prawidłowe odniesienie do ich praw.

Postawy rodzicielskie mają istotny wpływ na kształt społecznych postaw dzieci. Tolerancja jako wartość społeczna powinna być formowana od wczesnego dzieciństwa. To formowanie dokonuje się nie tylko poprzez zamierzone oddziaływania wychowawcze, ale również przez uczestnictwo w codziennym życiu rodziny, w którym nie brak spontaniczności. Dużą rolę w tej przestrzeni odgrywa mechanizm modelowania, poprzez który dzieci przejmują sposoby zachowania i postawy rodziców. Dlatego w kształtowaniu postawy tolerancji ważna jest jakość życia rodzinnego.

\section{Rodzina jako model tolerancji}

Życie rodzinne wymaga wiele trudu, by mogło być realizowane w poczuciu jedności i komunii: „Komunia rodzinna może być zachowana i doskonalona jedynie w wielkim duchu ofiary. Wymaga bowiem szlachetnej gotowości każdego i wszystkich do zrozumienia, tolerancji, przebaczenia i pojednania" (FC 21). Tolerancja jako postawa niezbędna w codziennym funkcjonowaniu rodziny jest więc jednym z zasadniczych celów, które winny być realizowane w wychowaniu rodzinnym. Warto zauważyć, iż pierwszym poziomem tolerancji w rodzinie, której domaga się papież, jest ofiarne „znoszenie” siebie nawzajem w cierpliwości i szacunku. Jest to konieczne ze względu na wymagania, które życie rodzinne stawia przed członkami rodziny.

W wypowiedzi papieskiej znajdują się też odniesienia do kształtowania pozytywnej postawy tolerancji, w której nie brak wzajemnej troski i gotowości do zrozumienia, przebaczenia i pojednania. Metodą, o której pisze papież, jest otwartość poszczególnych członków rodziny, która owocuje efektami wychowawczymi:

\footnotetext{
${ }^{33}$ Por. J. Brągiel, S. Kawula, Więzi społeczne w rodzinie, [w:] Pedagogika rodziny..., dz. cyt., s. 118.

${ }^{34}$ Jan Paweł II, adhort. apost. Familiaris consortio, 26 [dalej: FC].
} 
Podstawowym czynnikiem w budowaniu takiej komunii jest wymiana wychowawcza między rodzicami i dziećmi, w której każdy daje i otrzymuje. Dzieci poprzez miłość, szacunek, posłuszeństwo dla rodziców wnoszą swój szczególny i niezastąpiony wkład w budowanie rodziny autentycznie ludzkiej i chrześcijańskiej. Zadanie to będzie ułatwione, jeśli rodzice będą wykonywać swoją niezbywalną władzę jako prawdziwą i właściwą „służbę”, czyli posługę podporządkowaną dobru ludzkiemu i chrześcijańskiemu dzieci, a w szczególności umożliwieniu im osiągnięcia prawdziwie odpowiedzialnej wolności, oraz jeśli rodzice zachowają żywą świadomość „daru”, który stale otrzymują w dzieciach (FC 21).

Gdy więzi społeczne w rodzinie kształtowane są przez wzajemną miłość, postawy prospołeczne kształtowane są w sposób naturalny. Można przyjąć, że „zadanie rodziny w zakresie rozpoznania i przyswojenia wartości spoczywa na odpowiednim wewnętrznym systemie normatywnym, który miałby względem wartości charakter odsłaniający"35. Postawy rodziców winny być na tyle czytelne, by pomagały dzieciom odkryć prawdziwe wartości. Konieczne jest więc podkreślenie myśli wyrażonej przez bł. Jana Pawła II, według którego rodzice winni rozwijać wolność dziecka, ucząc go jej właściwego wykorzystania. Wymiana wychowawcza w rodzinie, o której mówi papież, jest wyrazem otwartości i gotowości do dialogu, a przecież to on znajduje się u podstaw prawdziwej tolerancji.

Powyższe postulaty realizują się w rodzinie opartej o relacje partnerskie, które nie oznaczają zrównania w funkcjach, prawach i obowiązkach rodziców i dzieci, ale dotyczą „sposobu komunikowania się i współdziałania oraz charakteru międzyosobowych odniesień" ${ }^{\text {"3 }}$. Traktowanie drugiego człowieka jako partnera wyraża akceptację jego osoby i stawia go wyżej niż wszelkie jego wytwory. Otwartość członków rodziny na siebie

posiada wartość ze względu na pozbawienie tych relacji intencji interesownej, względu na korzyść własną. Przebywanie ze sobą, dialog, w którym ma miejsce wzajemne otwieranie się na siebie, słuchanie, udzielanie wsparcia, zrozumienie, szukanie rozwiązań w problemach - to wszystko stanowi afirmację człowieka i jednocześnie warunkuje osobowe spełnienie ${ }^{37}$.

Personalistyczny wydźwięk powyższej wypowiedzi jeszcze raz podkreśla wartość wychowania rodzinnego w kształtowaniu postawy tolerancji. Wychowankowi, który dorasta w atmosferze prawdziwej miłości, będzie łatwiej przeciwstawić się stereotypom ograniczającym wolność i prawa innych ludzi. Jednocześnie wyraźne aksjologiczne umocowanie postawy tolerancji zabezpiecza ją przed redukcyjnym

${ }^{35} \mathrm{G}$. Grzybek, Wychowanie spoleczne i moralne w rodzinie, [w:] Wybrane zagadnienia ..., dz. cyt., s. 197.

${ }^{36}$ A. Regulska, Etyczno-pedagogiczny wymiar relacji partnerskich w rodzinie, [w:] Partnerstwo..., dz. cyt., s. 138.

${ }^{37}$ Tamże, s. 139. 
spojrzeniem na jej istotę. Konkludując, można wskazać kilka sposobów kształtowania partnerskich postaw w rodzinie. Należą do nich: troska o autentyczne, pozbawione fałszu zachowania, unikanie metod manipulacyjnych, opartych na półprawdach, kształtowanie postawy prawdy, nawet gdy jest ona trudna do przyjęcia, ukazywanie wartości odwagi w byciu autentycznym, unikanie zachowań dwuznacznych i niekonsekwentnych, troska o wyjaśnianie niedomówień, korygowanie kłamstw medialnych lub pochodzących od grup rówieśniczych, ukazywanie form mówienia prawdy z poszanowaniem drugiej osoby ${ }^{38}$.

Każde z powyższych działań wychowawczych ma swoje odniesienie do postawy tolerancji. Partnerski wymiar więzi rodzinnych jest odzwierciedlany poprzez relacje społeczne oparte na wzajemnym szacunku, a podnoszenie poziomu wychowawczego funkcjonowania rodziny stanowi czynnik poprawiający jakość życia społecznego.

Tolerancja i wychowanie w rodzinie są ze sobą ściśle związane. Kształtowanie się osobowości człowieka w warunkach życia rodzinnego nie pozostaje bez wpływu na jakość postaw obecnych w społeczeństwie. Mimo że w zdefiniowaniu tolerancji występuje dużo rozbieżności, jest ona wartością społecznie bardzo pożądaną. Warto podkreślić, iż dla procesu wychowania nie jest obojętne, jakie znaczenie przypisze się kategorii tolerancji. Jeśli będzie ona ujmowana zgodnie z założeniami liberalnymi, wychowanie do niej również będzie miało charakter liberalny. W ślad za tym osobowość wychowanka będzie kształtowana w oparciu o nastawienie na prawie bezkrytyczną afirmację poglądów drugiego człowieka. Utopijny charakter tej postawy nie wnosi jednak do społeczeństwa trwałych rozwiązań.

Wychowanie do tolerancji mającej silne odniesienie aksjologiczne na pierwsze miejsce wysuwa wartość osoby. Człowiek jest ważniejszy od poglądów, które posiada, i dlatego zawsze należy mu się szacunek. Świadomość odmienności przekonań i postaw nie musi oznaczać zamknięcia na to, co inne, i zaburzać relacji z drugim człowiekiem. Wychowanie do tolerancji uwzględniającej potrzebę otwarcia, szukania wspólnych rozwiązań, ale jednocześnie domagającej się zachowania własnej tożsamości jest istotnym zadaniem wychowania w rodzinie.

Partnerstwo w rodzinie, które stanowi podstawę wychowania demokratycznego, jest ważnym elementem wpływającym na postawę tolerancji. Wychowanie w oparciu o partnerskie relacje, w których nie ma zaburzenia podstawowych ról społecznych, może przynieść optymalne efekty. By jednak rodzina mogła rzeczywiście funkcjonować na zasadzie partnerskich relacji, konieczne jest nieustanne odwoływanie się w procesie wychowania do wartości o charakterze uniwersalnym. Bezinteresowna miłość, która winna być u podstaw życia i wychowania rodzinnego, stanowi najlepszą gwarancję tolerancji, jakże potrzebnej w domu i w społeczeństwie.

\footnotetext{
${ }^{38}$ J. Mastalski, Samotność globalnego nastolatka, Kraków 2007, s. 496.
} 
Postawy rodzicielskie stanowią istotny czynnik w wychowaniu dziecka do tolerancji. Ich kształtowanie wymaga sporo trudu, ale jest ono korzystne dla jednostki, rodziny i społeczeństwa. Wydaje się, że podnoszenie poziomu wychowawczego rodziny jest postulatem, który winien być ustawicznie realizowany. Braki w zakresie wychowania rodzinnego winny przyczynić się do jeszcze większej mobilizacji sił społecznych, by w ten sposób pokazywać, że rodzina wciąż stanowi najbardziej naturalną, a jednocześnie najdoskonalszą formę socjalizacji. Wydaje się, że w kolejnych analizach naukowych istotne byłoby wskazanie czynników wspierających zadania rodziny w wychowaniu dzieci do postawy tolerancji.

\section{Summary}

\section{Family upbringing as a factor developing social tolerance}

Tolerance is closely connected with upbringing. Forming one's personality within the family environment influences the quality of attitudes in the society. The educational process aimed at developing tolerance emphasizes that the value of a person should always be most important. Partnership in the family which forms the basis for democratic upbringing is a crucial element helping to develop tolerance. The upbringing based on relationships which are not distorted may be very effective. To enable the family to base their life on genuine partnership it is necessary to refer to universal values during the educational process. Selfless love which should be the foundation of life and upbringing is the best guarantee of social tolerance.

\section{Keywords}

Tolerance, upbringing, family, society 